\title{
Effect of inactive dry yeast from sugar cane as protein source on rumen fermentation in Saanen goats
}

\author{
[Efeito da levedura seca inativa da cana-de-açúcar como fonte de proteína sobre a fermentação \\ ruminal de caprinos Saanen] \\ L.S. Lima $^{1}$, C.R. Alcalde ${ }^{2,3}$, L.C. Gomes ${ }^{1}$, R. Souza ${ }^{1}$, L.P. Rigolon ${ }^{2}$, C.V. Nakamura ${ }^{2,3}$ \\ ${ }^{1}$ Aluno de pós-graduação - Universidade Estadual de Maringá - Maringá, PR \\ ${ }^{2}$ Universidade Estadual de Maringá - Maringá, PR \\ ${ }^{3}$ Pesquisador de Produtividade do $\mathrm{CNPq}$
}

\begin{abstract}
Five castrated and ruminally cannulated Saanen goats $( \pm 48.19 \mathrm{~kg})$ were used to evaluate intake, digestibility and rumen fermentation parameters of diets with inactive dry yeast as a soybean meal substitute $(0,25,50,75$ and $100 \%)$. Goats were randomly assigned to a $5 \times 5$ (five levels of dry yeast $\mathrm{x}$ five periods) Latin square design. Diets were composed of corn silage (40\%), ground corn, soybean meal and/or dry yeast and mineral supplement. The intake and digestibility of DM, OM, CP, NDF and TC were not influenced by the treatments. However, EE intake showed negative linear effect. The TDN content did not change with the inclusion of dry yeast in the diets. The $\mathrm{pH}, \mathrm{N}-\mathrm{NH}_{3}$ concentration and rumen short-chain fatty acids content did not differ among diets. Rumen content scanning electron microscopy observations did not suggest microbial colonization and degradation changes. Dry yeast from sugar cane can replace soybean meal in diets for Saanen goats without changing the rumen fermentation pattern, intake and digestibility.
\end{abstract}

Keywords: ammonia, digestibility, goats, Saccharomyces cerevisiae

\section{RESUMO}

Com o objetivo de avaliar a ingestão, a digestibilidade e os parâmetros de fermentação ruminal de rações com de levedura seca em substituição ao farelo de soja (0; 25; 50; 75 e 100\%), foram utilizados cinco caprinos Saanen $( \pm 48,19 \mathrm{~kg})$ castrados e canulados no rúmen distribuídos em quadrado latino $5 x$ 5 (cinco níveis $x$ cinco períodos). As rações foram compostas de silagem de milho (40\%), milho moído, farelo de soja elou levedura seca e suplemento vitamínico-mineral. A ingestão e a digestibilidade da MS, $M O, P B, F D N$ e dos $C T$ não foram alteradas. A ingestão de EE apresentou efeito linear negativo. $O$ NDT não foi alterado com a inclusão da levedura seca. $\mathrm{O}$ pH e as concentrações de $\mathrm{N}_{-} \mathrm{NH}_{3}$ e de ácidos graxos de cadeia curta no rúmen não apresentaram alterações. As observações por microscopia eletrônica de varredura não indicaram mudanças na colonização microbiana e na degradação da digesta ruminal. A levedura seca da cana-de-açúcar não altera o padrão de fermentação ruminal, a ingestão e a digestibilidade, podendo substituir o farelo de soja em rações de caprinos Saanen.

Palavras-chave: amônia, caprinos, digestibilidade, Saccharomyces cerevisiae

\section{INTRODUCTION}

Goats have unique characteristics when compared to other domestic ruminants. They are able to reduce feed particle size because of their efficient chewing and rumination activities.
Moreover, goats can be fed diets both high in fiber and high in concentrate, with good resistance to rumen acidosis. Therefore, goats can be raised in intensive and extensive systems (Rapetti and Bava, 2008), and total mixed ration is useful to supply nutritional requirements for meat and milk production.

Recebido em 30 de julho de 2010

Aceito em 27 de outubro de 2011

*Autor para correspondência (corresponding author)

E-mail: luciano.delima@hotmail.com 
Some by-product feeds have been evaluated in ruminant nutrition (Azevêdo et al., 2011; Correia et al., 2011). For goats, Bueno et al. (2002) and Alcalde et al. (2009) observed that soybean hulls and citrus pulp can replace corn in rations. The Brazilian ethanol industry produces about 75,000 tons of inactive dry yeast every year (Santos, 2009) which may have an attractive sale benefit for food industries (Amorim and Lopes, 2009).

Dry yeast from sugar cane (Saccharomyces cerevisiae) has approximately five billion inactive cells per gram of product (Santos, 2009) and may present approximately $42 \%$ crude protein (Butolo, 2002), and 20\% total nitrogen may be nucleic acids (Amorim and Lopes, 2009). Thus, dry yeast from sugar cane can be a good source of nitrogen for ruminants.

Lima et al. (2011) reported that dry yeast has good nutritional value for growing and finishing kids. Freitas et al. (2011) evaluated nitrogen balance in Saanen goats fed diets with dry yeast replacing soybean meal and observed that dry yeast allows the effective use of nitrogen compounds without changing nitrogen balance.

The understanding of the interaction between feed and rumen microorganisms is an important issue for ruminant feed evaluation. This is because diet ingredients and fermentation rates of nutrients can influence the fermentation products and their synthesis, which can affect feed intake (Provenza et al., 2003).

Thus, this study was carried out to evaluate the parameters of rumen fermentation, intake and digestibility of diets containing dry yeast from sugar cane replacing soybean meal in Saanen goats.

\section{MATERIAL AND METHODS}

The experiment was carried out at Fazenda Experimental de Iguatemi (Universidade Estadual de Maringá, Paraná - Brazil). Five castrated Saanen goats (averaging $48.19 \mathrm{~kg}$ of BW) fitted with ruminal cannulas were used. Goats were randomly assigned to five dietary treatments in a $5 \times 5$ Latin square design over five 15-d periods (10 days for adaptation and five days to collect data and samples). Treatments consisted of the replacement of soybean meal with dry yeast at the following levels: $0,25,50$, 75 and $100 \%$. The other ingredients in the diets were ground corn, vitamin and mineral supplement and corn silage with forage to concentrate ratio of 40:60 (Table 1 and 2). The inactive dry yeast was obtained by drying (spray drier) the biomass generated in sugar cane alcoholic fermentation.

Goats were fed twice daily (9:00a.m and 4:00 p.m.) with a total mixed ration; they also had free access to clean drinking water. The amounts of diet fed per day were calculated to meet the nutritional requirements $(2.7 \mathrm{Mcal} \mathrm{ME} / \mathrm{kg} \mathrm{DM}$ and $16.0 \%$ crude protein) according to AFRC (Nutrition..., 1998), providing around 10\% of orts, which were weighed and recorded daily before the 9:00 a.m. feeding.

Animals were weighed before feeding at the beginning of each period to adjust the amount of feed supplied. Dry matter intake was calculated using the dry matter (DM) from total mixed ration and the DM refused in orts.

Table 1. Chemical composition of the feeds

\begin{tabular}{lllll}
\hline \multirow{2}{*}{ Item } & \multicolumn{3}{c}{ Ingredients } \\
\cline { 2 - 5 } & $\begin{array}{l}\text { Ground } \\
\text { corn }\end{array}$ & $\begin{array}{l}\text { Soybean } \\
\text { meal }\end{array}$ & $\begin{array}{l}\text { Dry } \\
\text { yeast }\end{array}$ & Corn silage \\
\hline Dry matter $(\%)$ & 88.42 & 88.82 & 92.91 & 30.85 \\
Organic matter (\%DM) & 98.66 & 92.96 & 96.29 & 96.17 \\
Ash $(\% \mathrm{DM})$ & 1.34 & 7.04 & 3.71 & 3.83 \\
Crude protein (\%DM) & 9.90 & 50.64 & 40.44 & 7.55 \\
Rumen degradable protein $(\% \mathrm{DM})$ & 4.05 & 32.94 & 42.86 & 5.10 \\
Ether extract $(\% \mathrm{DM})$ & 4.13 & 2.59 & 0.43 & 3.05 \\
Neutral detergent fiber $(\% \mathrm{DM})$ & 16.32 & 13.45 & - & 66.58 \\
Acid detergent fiber $(\% \mathrm{DM})$ & 4.62 & 8.95 & - & 28.25 \\
Total carbohydrates $(\% \mathrm{DM})$ & 84.63 & 39.73 & 55.85 & 85.57 \\
\hline
\end{tabular}


Effect of inactive dry...

Table 2. Ingredients and chemical composition of experimental diets

\begin{tabular}{llllll}
\hline & \multicolumn{5}{c}{ Level of dry yeast (\%) } \\
\cline { 2 - 6 } Item & 0 & 25 & 50 & 75 & 100 \\
\hline Corn silage (\%DM) & 40.00 & 40.00 & 40.00 & 40.00 & 40.00 \\
Ground corn (\%DM) & 38.00 & 37.20 & 35.00 & 33.00 & 31.00 \\
Soybean meal (\%DM) & 19.02 & 14.80 & 11.00 & 7.20 & - \\
Dry yeast (\%DM) & & 5.00 & 11.00 & 16.80 & 26.00 \\
Mineral and vitamin supplement ${ }^{1}(\% \mathrm{DM})$ & 3.00 & 3.00 & 3.00 & 3.00 & 3.00 \\
\hline Dry matter (\%) & 65.57 & 65.91 & 66.09 & 66.31 & 66.47 \\
Organic matter (\%DM) & 94.23 & 94.23 & 94.01 & 94.24 & 94.48 \\
Ash (\%DM) & 5.86 & 5.86 & 5.99 & 576 & 5.52 \\
Crude protein (\%DM) & 16.34 & 15.67 & 16.32 & 16.25 & 16.56 \\
Rumen degradable protein (\%DM) & 9.80 & 10.55 & 11.79 & 12.94 & 14.43 \\
Ether extract (\%DM) & 3.18 & 3.01 & 2.90 & 2.64 & 2,41 \\
Neutral detergent fiber (\%DM) & 34.25 & 33.48 & 32.20 & 31.54 & 30.15 \\
Indigestible neutral detergent fiber (\%DM) & 11.52 & 11.09 & 10.36 & 10.64 & 10.25 \\
Acid detergent fiber (\%DM) & 15.37 & 14.46 & 13.93 & 13.09 & 12.99 \\
Total carbohydrates (\%DM) & 74.71 & 75.46 & 74.79 & 75.35 & 75.50 \\
NDT (\%DM) & 72.72 & 72.66 & 72.55 & 72.45 & 72.35 \\
EL (Mcal/kg MS) & 2.63 & 2.63 & 2.63 & 2.62 & 2.62 \\
\hline Chemyyyyyyyyyyy
\end{tabular}

${ }^{1}$ Chemical composition (per kg of product): A vitamin 135,000.00UI; D3 vitamin D3 68,000.00UI; E vitamin E 450.00UI; Ca 240.00g; P 71.00g; K 28.20g; S 20.00g S; Mg 20.00g; Cu 400.00mg; Co 30.00mg; Cr 10.00mg; Fe 2,500.00mg; I 40.00mg; Mn 1,350.00mg; Se 15,00mg; Zn 1,700.00mg; F 710.00mg (max); Citric acid (2\%) solubility of phosphorus $95 \%$ ( $\mathrm{min}$ ) - commercial product.

Food and orts were sampled once daily (on the last five days of each experimental period before the first meal) and stored at $-20^{\circ} \mathrm{C}$ until use. Samples of feces were collected for five consecutive days at $8 \mathrm{~h}$ on $\mathrm{d} 11,10 \mathrm{~h}$ on $\mathrm{d} 12,12$ $\mathrm{h}$ on $\mathrm{d} 13,14 \mathrm{~h}$ on $\mathrm{d} 14,16 \mathrm{~h}$ on $\mathrm{d} 15$ of each experimental period and stored at $-20^{\circ} \mathrm{C}$ until use.

Samples (food, orts and feces) were oven-dried $\left(55^{\circ} \mathrm{C}\right.$ for $\left.72 \mathrm{~h}\right)$, then ground in a cutter mill to pass through a $1-\mathrm{mm}$ screen sieve. Equal DM from each fecal subsample was mixed to obtain a single composite for each sampled goat during each period.

Dry matter was evaluated according to method no. 934.01 of AOAC (Official..., 1998). Organic matter was determined by combustion in a muffle furnace according to method no. 942.05 of AOAC (Official..., 1998). Total nitrogen (TN) determination used a Tecnal TE-036/1 (Tecnal, Piracicaba, São Paulo, Brazil) following method no. 988.05 of AOAC (Official..., 1998) and crude protein (CP) was estimated as $\mathrm{TN} \times 6.25$. Ether extraction in diets was conducted with Tecnal TE-044/1 according to method no. 920.39 of AOAC (Official..., 1998). The neutral detergent fiber (NDF) was evaluated as described by Mertens (2002) using a heat-stable $\alpha$-amylase, without using sodium sulphite. Procedures for NDF determination were adapted to the Ankom $^{200}$ filter bag technique. The ADF content was determined according to AOAC (Official..., 1998) method no. 973.18.

The dietary rumen degradable protein (RDP) content was calculated according to the NRC (Nutrient..., 2001) model. The considered values were $70 \%, 48 \%, 65 \%$ and $100 \%$ for corn silage, ground corn, soybean meal and dry yeast, respectively.

Total carbohydrates (TC) and total digestible nutrients (TDN) were estimated according to equations described by Sniffen et al. (1992): $\mathrm{TC}(\%)=100-(\% \mathrm{CP}+\% \mathrm{EE}+\% \mathrm{ash})$ and TDN $=\mathrm{DCP}+(2.25 \mathrm{x}$ DEE $)+\mathrm{DTC}$, which 
$\mathrm{DCP}=$ digestible crude protein, $\mathrm{DEE}=$ digestible ether extract and DTC = digestible total carbohydrates.

Indigestible NDF (iNDF) was used as an internal marker to estimate fecal output and apparent nutrient digestibility. For iNDF analysis, $0.5 \mathrm{~g}$ $(1 \mathrm{~mm})$ of period samples (fecal, orts and feeds) were in situ incubated (144h) in the rumen of goats within nylon bags (F57 Ankom) followed by neutral detergent analysis (Mertens, 2002) by using a Ankom ${ }^{200}$ Fiber Analyzer (Ankom Technology Corp., Fairport, NY).

Rumen content was sampled on the last day (15) of each experimental period from the anterior dorsal, anterior ventral, medium ventral, posterior dorsal, and posterior ventral locations within the rumen. Samples were homogenized and strained through four layers of cheesecloth. For $\mathrm{pH}$ and ammonia $\mathrm{N}\left(\mathrm{NH}_{3}-\mathrm{N}\right)$ measures, the samples were collected before feeding and $1 \mathrm{~h}$, $3 \mathrm{~h}$, and $6 \mathrm{~h}$ after feeding. Rumen $\mathrm{pH}$ value was measured immediately with a standardized laboratory $\mathrm{pH}$ meter at each sampling time point. Ammonia $\mathrm{N}$ concentration was determined from subsamples $(50 \mathrm{~mL})$ of filtered rumen fluid added of $1 \mathrm{~mL}$ sulfur acid $(1: 1)$ and stored at $20^{\circ} \mathrm{C}$, as described by Preston (1995).

To determine the short-chain fatty acids (SCFA), samples were taken at $3 \mathrm{~h}$ and $6 \mathrm{~h}$ after morning and afternoon feedings. Samples were mixed to obtain a single composite for each sampled goat during each period and then stored at $-20^{\circ} \mathrm{C}$ until use, when they were centrifuged at $15,000 \times \mathrm{g}$ $\left(4^{\circ} \mathrm{C}\right)$ for 50 minutes and analyzed according to the technique described by Campos et al. (2004) in gas-liquid chromatograph (Hewlett Packard 5890 Series II GC) equipped with an integrator (Hewlett Packard 3396 Series II Integrator) and an automatic injector (Hewlett Packard 6890 Series Injector). The internal standard used was 2-methylbutyric acid. Within each chromatography reading tube there was an addition of $100 \mu \mathrm{L}$ of internal standard, $800 \mu \mathrm{L}$ sample and $200 \mu \mathrm{L}$ of formic acid. A known concentration mixture of SCFA was used as external standard for the calibration of the integrator.
Rumen content samples were taken to analyze through scanning electron microscopy (SEM) at $3 \mathrm{~h}$ and $6 \mathrm{~h}$ after morning feeding. Samples were immediately fixed in glutaraldehyde $(3 \%)$ in buffer (0.05 $M$ potassium cacodylate) and kept at $4^{\circ} \mathrm{C}$. Then the samples were centrifuged $(3 \mathrm{x}$ $3 \mathrm{~min})$ with buffer (0.05 $M$ potassium cacodylate) in $1: 3(\mathrm{v}: \mathrm{v})$ proportion. After centrifugations, the samples were dehydrated, metallized with gold palladium and observed in Scanning Electron Microscope Shimadzu ${ }^{\circledR}$, according to the technique described by Souza (1998).

The data was submitted to analysis of variance and regression at the level of 5\% significance, using the SAEG program (Sistema..., 1997).

\section{RESULTS AND DISCUSSION}

There was no significant treatment effect $(\mathrm{P}>0.05)$ on dry matter intake, organic matter, crude protein, neutral detergent fiber, total carbohydrate and total digestible nutrients (Table 3). Prado et al. (2000) reported that dry yeast may limit food intake in heifers and it can be associated with the fine texture of this feed. However, this negative effect was not shown on the intake of goats of this experiment. This agrees with Lima et al. (2011), who reported that feeding dry yeast as a soybean meal substitute, did not alter dry matter intake and nutrient intake.

There was a linear effect of intake of ether extract with dry yeast inclusion. This is associated to the lowest level of this nutrient in dry yeast (Table 1) which decreased the ether extract content in the total mixed ration (Table 2).

The coefficients of digestibility of dry matter, organic matter, crude protein, neutral detergent fiber and total carbohydrates were not affected $(\mathrm{P}>0.05)$ by the inclusion of dry yeast in the diets (Table 3). However, the inclusion of dry yeast resulted in a quadratic effect on the digestibility of ether extract (Table 3). The maximum digestibility coefficient was estimated for level $38.5 \%$ of dry yeast in the diet. 
Effect of inactive dry...

Table 3. Intake and digestibility of dry matter and nutrients, and total digestible nutrients (TDN) of diets in Saanen goats fed inactive dry yeast as protein source

\begin{tabular}{|c|c|c|c|c|c|c|c|c|}
\hline \multirow{2}{*}{ Item $^{1}$} & \multicolumn{5}{|c|}{ Level of dry yeast (\%) } & \multirow{2}{*}{ Regression } & \multirow{2}{*}{$\mathrm{R}^{2}$} & \multirow{2}{*}{$\mathrm{VC}$} \\
\hline & 0 & 25 & 50 & 75 & 100 & & & \\
\hline \multicolumn{9}{|c|}{ Intake $(\mathrm{kg} / \mathrm{d})$} \\
\hline $\mathrm{DM}$ & $\begin{array}{l}1.028 \pm \\
0.06\end{array}$ & $\begin{array}{l}1.072 \pm \\
0.06\end{array}$ & $\begin{array}{l}1.027 \pm \\
0.06\end{array}$ & $\begin{array}{l}1.126 \pm \\
0.06\end{array}$ & $\begin{array}{l}1.090 \pm \\
0.06\end{array}$ & $Y=1.068$ & $\mathrm{NS}^{2}$ & 13.06 \\
\hline $\mathrm{OM}$ & $\begin{array}{l}0.969 \pm \\
0.06\end{array}$ & $\begin{array}{l}1.001 \pm \\
0.06\end{array}$ & $\begin{array}{l}0.966 \pm \\
0.06\end{array}$ & $\begin{array}{l}1.060 \pm \\
0.06\end{array}$ & $\begin{array}{l}1.030 \pm \\
0.06\end{array}$ & $\mathrm{Y}=1.007$ & NS & 12.87 \\
\hline $\mathrm{CP}$ & $\begin{array}{l}0.178 \pm \\
0.01\end{array}$ & $\begin{array}{l}0.178 \pm \\
0.01\end{array}$ & $\begin{array}{l}0.175 \pm \\
0.01\end{array}$ & $\begin{array}{l}0.189 \pm \\
0.01\end{array}$ & $\begin{array}{l}0.178 \pm \\
0.01\end{array}$ & $Y=0.179$ & NS & 13.41 \\
\hline $\mathrm{EE}$ & $\begin{array}{l}0.033 \pm \\
0.00\end{array}$ & $\begin{array}{l}0.033 \pm \\
0.00\end{array}$ & $\begin{array}{l}0.030 \pm \\
0.00\end{array}$ & $\begin{array}{l}0.030 \pm \\
0.00\end{array}$ & $\begin{array}{l}0.027 \pm \\
0.00\end{array}$ & $\begin{array}{l}Y=0.03366- \\
0.0006175 X\end{array}$ & 0.87 & 13.15 \\
\hline $\mathrm{NDF}$ & $\begin{array}{l}0.331 \pm \\
0.02\end{array}$ & $\begin{array}{l}0.333 \pm \\
0.02\end{array}$ & $\begin{array}{l}0.308 \pm \\
0.02\end{array}$ & $\begin{array}{l}0.341 \pm \\
0.02\end{array}$ & $\begin{array}{l}0.290 \pm \\
0.02\end{array}$ & $\mathrm{Y}=0.321$ & NS & 12.49 \\
\hline $\mathrm{TC}$ & $\begin{array}{l}0.758 \pm \\
0.05\end{array}$ & $\begin{array}{l}0.798 \pm \\
0.05\end{array}$ & $\begin{array}{l}0.761 \pm \\
0.05\end{array}$ & $\begin{array}{l}0.841 \pm \\
0.05\end{array}$ & $\begin{array}{l}0.826 \pm \\
0.05\end{array}$ & $\mathrm{Y}=0.797$ & NS & 12.82 \\
\hline TDN & $\begin{array}{l}0.788 \pm \\
0.05\end{array}$ & $\begin{array}{l}0.812 \pm \\
0.05\end{array}$ & $\begin{array}{l}0.782 \pm \\
0.05\end{array}$ & $\begin{array}{l}0.853 \pm \\
0.05\end{array}$ & $\begin{array}{l}0.827 \pm \\
0.05\end{array}$ & $\mathrm{Y}=0.813$ & NS & 13.03 \\
\hline \multicolumn{9}{|c|}{ Digestibility (\%) } \\
\hline $\mathrm{DM}$ & $\begin{array}{l}73.89 \pm \\
2.01\end{array}$ & $\begin{array}{l}73.84 \pm \\
2.01\end{array}$ & $\begin{array}{l}70.45 \pm \\
2.01\end{array}$ & $\begin{array}{l}74.45 \pm \\
2.01\end{array}$ & $\begin{array}{l}74.75 \pm \\
2.01\end{array}$ & $Y=73.48$ & NS & 6.13 \\
\hline $\mathrm{OM}$ & $\begin{array}{l}77.68 \pm \\
1.55\end{array}$ & $\begin{array}{l}77.28 \pm \\
1.55\end{array}$ & $\begin{array}{l}74.93 \pm \\
1.55\end{array}$ & $\begin{array}{l}77.51 \pm \\
1.55\end{array}$ & $\begin{array}{l}78.03 \pm \\
1.55\end{array}$ & $Y=77.09$ & NS & 4.50 \\
\hline $\mathrm{CP}$ & $\begin{array}{l}69.65 \pm \\
1.64\end{array}$ & $\begin{array}{l}68.7 \pm \\
1.64\end{array}$ & $\begin{array}{l}68.31 \pm \\
1.64\end{array}$ & $\begin{array}{l}70.47 \pm \\
1.64\end{array}$ & $\begin{array}{l}69.59 \pm \\
1.64\end{array}$ & $\mathrm{Y}=69.31$ & NS & 5.30 \\
\hline $\mathrm{EE}$ & $\begin{array}{l}87.07 \pm \\
1.41\end{array}$ & $\begin{array}{l}86.73 \pm \\
1.41\end{array}$ & $\begin{array}{l}88.26 \pm \\
1.41\end{array}$ & $\begin{array}{l}87.87 \pm \\
1.41\end{array}$ & $\begin{array}{l}82.60 \pm \\
1.41\end{array}$ & $\begin{array}{l}Y=86.38+0.1035 X- \\
0.001346 X^{2}\end{array}$ & 0.78 & 3.64 \\
\hline $\mathrm{NDF}$ & $\begin{array}{l}56.99 \pm \\
2.26\end{array}$ & $\begin{array}{l}56.41 \pm \\
2.26\end{array}$ & $\begin{array}{l}52.50 \pm \\
2.26\end{array}$ & $\begin{array}{l}52.60 \pm \\
2.26\end{array}$ & $\begin{array}{l}52.03 \pm \\
2.26\end{array}$ & $Y=54.11$ & NS & 9.34 \\
\hline $\mathrm{TC}$ & $\begin{array}{l}79.16 \pm \\
1.65\end{array}$ & $\begin{array}{l}78.99 \pm \\
1.65 \\
\end{array}$ & $\begin{array}{l}75.93 \pm \\
1.65\end{array}$ & $\begin{array}{l}78.74 \pm \\
1.65\end{array}$ & $\begin{array}{l}79.69 \pm \\
1.65\end{array}$ & $Y=78.50$ & NS & 4.70 \\
\hline TDN & $\begin{array}{l}76.75 \pm \\
1.36\end{array}$ & $\begin{array}{l}76.18 \pm \\
1.36\end{array}$ & $\begin{array}{l}74.07 \pm \\
1.36\end{array}$ & $\begin{array}{l}76.00 \pm \\
1.36\end{array}$ & $\begin{array}{l}76.32 \pm \\
1.36\end{array}$ & $Y=75.87$ & NS & 4.00 \\
\hline
\end{tabular}

${ }^{1}$ DM: dry matter; OM: organic matter; CP: crude protein; EE: ether extract; NDF: neutral detergent fiber; TC: total carbohydrates.

${ }^{2} \mathrm{NS}$ : values were not significantly different $(\mathrm{P}>0.05)$.

Different effects of feeding dry yeast were observed by Lima et al. (2011) who reported an increase in crude protein digestibility, reduction in digestibility of ether extract, no effects on the neutral detergent fiber digestibility and increase of total digestible nutrients of diets with dry yeast in finishing kids. Martins et al. (2000) also reported improvement in the digestibility of crude protein and neutral detergent fiber in heifers fed rations with dry yeast. These differences may be related to the other ingredients in the rations (corn or cassava, hay or corn silage), species, sex and also the physiological stage of animals that can influence the availability of nutrients.
The observed total digestible nutrients did not differ $(\mathrm{P}>0.05)$ among diets. It can be explained by similar digestibility of most nutrients shown by diets.

Treatments did not influence $(\mathrm{P}>0.05)$ rumen $\mathrm{pH}$ (Table 4), and values averaged 6.22 over the sample period. Rumen $\mathrm{pH}$ lower than 6.2 can limit the degradation rate and increase colonization time in the degradation of cell wall (Van Soest, 1994). Thus, $\mathrm{pH}$ values provided by treatments appear appropriate for the rumen cellulolytic microorganisms, and the pattern of rumen fermentation among treatments was similar, because the $\mathrm{pH}$ is a consequence of microbial activity and rumen fermentation conditions (Wang et al., 2009). 
Table 4. Ruminal parameters in Saanen goats fed diets with different levels of dry yeast

\begin{tabular}{|c|c|c|c|c|c|c|c|c|}
\hline \multirow{2}{*}{ Item } & \multicolumn{5}{|c|}{ Level of dry yeast (\%) } & \multirow[b]{2}{*}{ Regression } & \multirow{2}{*}{$\mathrm{R}^{2}$} & \multirow{2}{*}{$\mathrm{VC}$} \\
\hline & 0 & 25 & 50 & 75 & 100 & & & \\
\hline $\mathrm{pH}$ & $\begin{array}{l}6.31 \pm \\
0.08\end{array}$ & $\begin{array}{l}6.23 \pm \\
0.08\end{array}$ & $\begin{array}{l}6.15 \pm \\
0.08\end{array}$ & $\begin{array}{l}6.21 \pm \\
0.08\end{array}$ & $6.18 \pm 0.08$ & $Y=6.22$ & $\mathrm{NS}^{1}$ & 2.71 \\
\hline $\mathrm{NH}_{3}-\mathrm{N}(\mathrm{mg} / \mathrm{dL})$ & $\begin{array}{l}16.24 \\
\pm 1.57\end{array}$ & $\begin{array}{l}19.64 \\
\pm 1.57\end{array}$ & $\begin{array}{l}21.39 \\
\pm 1.56\end{array}$ & $\begin{array}{l}17.93 \\
\pm 1.56\end{array}$ & $\begin{array}{l}20.25 \pm 1.5 \\
6\end{array}$ & $Y=19.09$ & NS & 18.33 \\
\hline Acetate $(\mathrm{m} M / \mathrm{mL})$ & $\begin{array}{l}49.51 \\
\pm 2.97\end{array}$ & $\begin{array}{l}49.34 \\
\pm 2.97\end{array}$ & $\begin{array}{l}46.63 \\
\pm 2.97\end{array}$ & $\begin{array}{l}38.18 \\
\pm 2.97\end{array}$ & $\begin{array}{l}46.63 \pm 2.9 \\
7\end{array}$ & $Y=46.08$ & NS & 14.46 \\
\hline Propionate $(\mathrm{m} M / \mathrm{mL})$ & $\begin{array}{l}14.91 \\
\pm 1.13\end{array}$ & $\begin{array}{l}16.96 \\
\pm 1.13\end{array}$ & $\begin{array}{l}18.30 \\
\pm 1.13\end{array}$ & $\begin{array}{l}17.13 \\
\pm 1.13\end{array}$ & $\begin{array}{l}18.40 \pm 1.1 \\
3\end{array}$ & $Y=17.14$ & NS & 14.75 \\
\hline Butyrate $(\mathrm{m} M / \mathrm{mL})$ & $\begin{array}{l}8.56 \pm \\
0.75\end{array}$ & $\begin{array}{l}8.61 \pm \\
0.75\end{array}$ & $\begin{array}{l}8.29 \pm \\
0.75\end{array}$ & $\begin{array}{l}7.87 \pm \\
0.75\end{array}$ & $\begin{array}{l}10.42 \pm 0.7 \\
5\end{array}$ & $Y=8.75$ & NS & 19.20 \\
\hline $\begin{array}{l}\text { Iso-Butyrate } \\
(\mathrm{m} M / \mathrm{mL})\end{array}$ & $\begin{array}{l}0.92 \pm \\
0.15\end{array}$ & $\begin{array}{l}0.87 \pm \\
0.15\end{array}$ & $\begin{array}{l}0.82 \pm \\
0.15\end{array}$ & $\begin{array}{l}0.61 \pm \\
0.02\end{array}$ & $0.85 \pm 0.15$ & $\mathrm{Y}=0.81$ & NS & 42.42 \\
\hline Valerate $(\mathrm{m} M / \mathrm{mL})$ & $\begin{array}{l}1.50 \pm \\
0.22\end{array}$ & $\begin{array}{l}0.73 \pm \\
0.22\end{array}$ & $\begin{array}{l}0.93 \pm \\
0.22\end{array}$ & $\begin{array}{l}1.36 \pm \\
0.22\end{array}$ & $1.28 \pm 0.22$ & $Y=1.16$ & NS & 41.99 \\
\hline $\begin{array}{l}\text { Iso-Valerate } \\
(\mathrm{m} M / \mathrm{mL})\end{array}$ & $\begin{array}{l}1.58 \pm \\
0.25\end{array}$ & $\begin{array}{l}0.97 \pm \\
0.25\end{array}$ & $\begin{array}{l}1.03 \pm \\
0.25\end{array}$ & $\begin{array}{l}1.22 \pm \\
0.25\end{array}$ & $1.45 \pm 0.25$ & $Y=1.25$ & NS & 44.35 \\
\hline $\begin{array}{l}\text { Total SCFA } \\
(\mathrm{m} M / \mathrm{mL})\end{array}$ & $\begin{array}{l}76.97 \\
\pm 4.59\end{array}$ & $\begin{array}{l}77.47 \\
\pm 4.59\end{array}$ & $\begin{array}{l}76.00 \\
\pm 4.59\end{array}$ & $\begin{array}{l}66.37 \\
\pm 4.59\end{array}$ & $\begin{array}{l}79.11 \pm 4.5 \\
9\end{array}$ & $Y=75.19$ & NS & 13.65 \\
\hline Acetate/Propionate & $\begin{array}{l}3.40 \pm \\
0.13\end{array}$ & $\begin{array}{l}2.93 \pm \\
0.13\end{array}$ & $\begin{array}{l}2.56 \pm \\
0.13\end{array}$ & $\begin{array}{l}2.27 \pm \\
0.13\end{array}$ & $2.55 \pm 0.13$ & $\begin{array}{l}Y=3.44- \\
0.0276 \mathrm{X}+ \\
0.000181 \mathrm{X} \\
2\end{array}$ & 0.97 & 10.47 \\
\hline
\end{tabular}

${ }^{\mathrm{T}} \mathrm{NS}$ : values were not significantly different $(\mathrm{P}>0.05)$.

Treatments did not influence $(\mathrm{P}>0.05)$ rumen $\mathrm{NH}_{3}-\mathrm{N}$ concentration (Table 4). Over the sampling period, $\mathrm{NH}_{3}-\mathrm{N}$ concentrations were maintained between 9 and $30 \mathrm{mg} / \mathrm{dL}$ and the values reached maximum points about $1 \mathrm{~h}$ after feeding. Rumen $\mathrm{NH}_{3}-\mathrm{N}$ is a product of microbial degradation from dietary protein, hydrolysis of the diet or endogenous compounds containing non-protein nitrogen and degradation of microbial cells (Merchen, 1988). Values of rumen $\mathrm{NH}_{3}-\mathrm{N}$ concentration were higher than $5 \mathrm{mg} / \mathrm{dL}$, as previously recommended by Satter and Slyter (1974) and Roffler and Satter (1975) for a suitable microbial growth. In goats, Lana et al. (2007) and Alcalde et al. (2009) reported values slightly higher $(15.77 \mathrm{mg} / \mathrm{dL}$ and $16.28 \mathrm{mg} / \mathrm{dL} \mathrm{NH}_{3}-\mathrm{N}$, respectively) than data of the present experiment. It is probably related to the composition of the diets, in which protein and rumen degradable protein content affect the rumen ammonia availability.

Dietary use of dry yeast did not alter $(\mathrm{P}>0.05)$ concentrations of acetate, propionate, butyrate, isobutyrate, valerate, isovalerate and total shortchain fatty acids (Table 4). Bergman (1990) reported that the molar proportions of short-chain fatty acids (SCFA) as acetate:propionate:butyrate in the rumen vary from 75:15:10 to 40:40:20. In rumen fluid of Saanen goats $( \pm 52.35 \mathrm{~kg})$ fed ground corn, soybean meal and corn silage (40\%), Zambom et al. (2007) observed 65:22:13 for acetate, propionate and butyrate ratio. In another experiment, Wang et al. (2009) reported 63:21:16 for acetate, propionate and butyrate ratio in kids $( \pm 26.2 \mathrm{~kg})$ fed diets with $68: 32$ forage:concentrate ratio with soybean meal and urea as nitrogen sources. Thus, in the current experiment the acetate:propionate:butyrate rate (64:24:12) agrees with previous data from experiment with goats.

Individually, SCFA values were similar among treatments. However, acetate/propionate reason had a quadratic effect and lower values were shown with $76.2 \%$ of dietary dry yeast inclusion (Table 4). Samples of rumen content collected $3 \mathrm{~h}$ after morning feeding and analyzed by scanning electron microscopy (SEM) revealed particles with damaged epidermis and colonized by rumen bacteria (Fig 1). Samples collected 6h after morning feeding appeared to also show damaged epidermis, microbial colonization, and fibrous tissue degradation (Fig. 2). However, the SEM 


\section{Effect of inactive dry...}

did not show changes among treatments related to microbial colonization and degradation. SEM is a qualitative analysis based on visual observations, and it may not represent the degradation of rumen content in each treatment effectively. However, the SEM images taken in
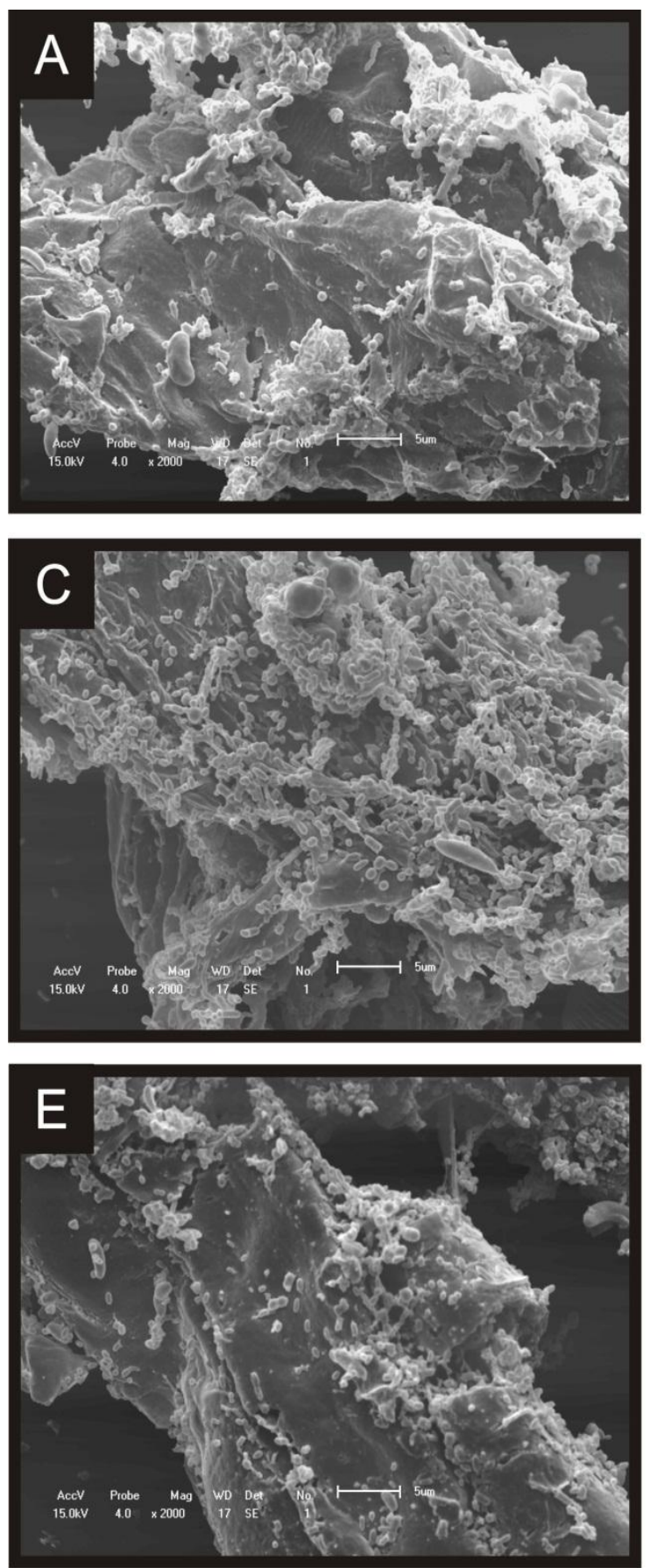

Figure 1. Scanning electron micrographs of the rumen content of Saanen goats $3 \mathrm{~h}$ after feeding (A: 0\% DY; B: $25 \%$ DY; C: $50 \%$ DY; D: $75 \%$ DY and E: $100 \%$ DY) 

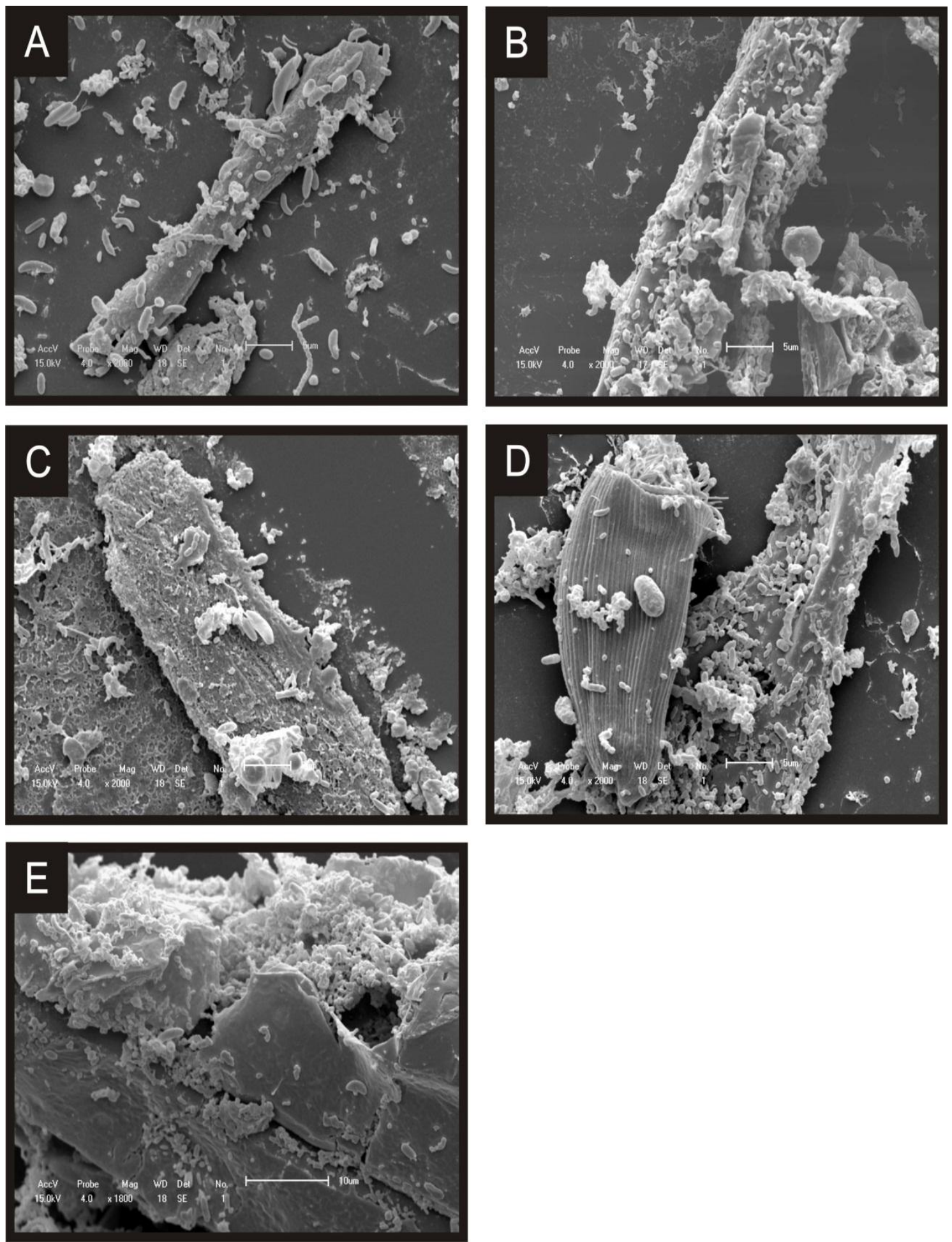

Figure 2.Scanning electron micrographs of the rumen content of Saanen goats $6 \mathrm{~h}$ after feeding (A: $0 \%$ DY; B: $25 \%$ DY; C: $50 \%$ DY; D: $75 \%$ DY and E: $100 \%$ DY) 


\section{CONCLUSIONS}

Dry yeast from sugar cane does not alter the pattern of rumen fermentation, intake and digestibility of diets, and may replace soybean meal in diets for Saanen goats.

\section{REFERENCES}

ALCALDE, C.R.; ZAMBOM, M.A.; PASSIANOTO, G.D.O. et al. Valor nutritivo de rações contendo casca do grão de soja em substituição ao milho moído para cabritos Saanen. Rev. Bras. Zootec., v.38, p.21982203, 2009.

AMORIM, H.V.; LOPES, M.L. Tecnologia sobre processamento de leveduras vivas, inativas e seus derivados: conceitos básicos. In: CONGRESSO SOBRE USO DE LEVEDURA NA ALIMENTAÇÃO ANIMAL, 1., 2009. Anais... Campinas: [s.n.] 2009. p.5. (Resumo).

AZEVÊDO, J.A.G.; VALADARES FILHO, S.C.; PINA, D.S. et al. Consumo, digestibilidade total, produção de proteína microbiana e balanço de nitrogênio em dietas para ruminantes de subprodutos. Arq. Bras. Med. Vet. Zootec., v.63, p.114-123, 2011.

BERGMAN, E.N. Energy contributions of volatile fatty acids from the gastrointestinal tract in various species. Physiol. Rev., v.70, p.567-590, 1990.

BUENO, M.S.; FERRARI JR., E.; BIANCHINI, D. et al. Effect of replacing corn with dehydrated citrus pulp in diets of growing kids. Small Rumin. Res., v.46, p.179-185, 2002.

BUTOLO, J.E. Qualidade de ingredientes na alimentação animal. Campinas: CBNA. 2002.180p.

CAMPOS, F.P.; NUSSIO, C.M.B.; NUSSIO, L.G. Métodos de análises de alimentos. Piracicaba: FEALQ. 2004. 135p.

CORREIA, B.R.; OLIVEIRA, R.L.; JAEGER, S.M.P.L. et al. Consumo, digestibilidade e $\mathrm{pH}$ ruminal de novilhos submetidos a dietas com tortas oriundas da produção do biodiesel em substituição ao farelo de soja. Arq. Bras. Med. Vet. Zootec., v.63, p.356-363, 2011.

FREITAS, H.S.; ALCALDE, C.R.; LIMA, L.S. et al. Digestibilidade total e balanço de nitrogênio em cabritos recebendo rações contendo levedura seca. Acta. Sci. Anim. Sci., v.33, p.281-286, 2011.

LANA, R.P.; CAMARDELLI, M.M.L.; RODRIGUES, M.T. et al. Óleo de soja e própolis na alimentação de cabras leiteiras: consumo de matéria seca e de nutrientes e parâmetros de fermentação ruminal. Rev. Bras. Zootec., v.34, p.191-197, 2007.
LIMA, L.S.; ALCALDE, C.R.; FREITAS, H.S. et al. Sugar cane dry yeast in feeding for growing and finishing goat kids. Rev. Bras. Zootec., v.40, p.168173, 2011.

MARTINS, A.S.; PRADO, I.N.; ZEOULA, L.M. et al. Digestibilidade aparente de dietas contendo milho ou casca de mandioca como fonte energética e farelo de algodão ou levedura como fonte protéica em novilhas. Rev. Bras. Zootec., v.29, p.269-277, 2000.

MERCHEN, N.R. Digestion, absorcion y excecion en los rumiantes. In: CHURCH, C.D. (Ed.) El rumiant, Fiología digestiva y nutrición.Zaragoza: Acríbia, 1988. p.191-223.

MERTENS, D.R. Gravimetric determination of amylase-treated neutral detergent fiber in feeds with refluxing in beakers or crucibles: collaborative study. J. AOAC Int., v.85, p.1217-1240, 2002.

NUTRIENTS requirements of dairy cattle. 7. Washington, D.C.: The National Academies Press. 2001.381p.

NUTRITION of goats.Wallingford:AFRC, 1998. $118 \mathrm{p}$.

OFFICIAL methods of analysis. 16.ed. Gaithersburg, M.P.: AOAC, 1998. 1141p.

PRADO, I.N.; MARTINS, A.S.; ALCALDE, C.R. et al. Desempenho de novilhas alimentadas com rações contendo milho ou casca de mandioca como fonte energética e farelo de algodão ou levedura como fonte protéica. Rev. Bras. Zootec., v.29, p.278-287, 2000.

PRESTON, T.R. Biological and chemical analytical methods. In: PRESTON, T.R. (Ed.) Tropical animal feeding: a manual for research workers. Rome: FAO, 1995. p.191-264.

PROVENZA, F.D.; VILLALBA, J.J.; DZIBA, L.E. et al. Linking herbivore experience, varied diets, and plant biochemical diversity. Small Rumin. Res., v.49, p.257-274, 2003.

RAPETTI, L.; BAVA, L. Feeding management of dairy goats in intensive systems. In: CANNAS, A.; PULINA, G. (Ed.) Dairy goats feeding and nutrition. 2.ed., Bologna, 2008. p.221-237.

ROFFLER, R.E.; SATTER, L.D. Relationship between ruminal ammonia and nonprotein nitrogen utilization by ruminants. I. Development of a model for predicting nonprotein nitrogen utilization by cattle. J. Dairy Sci., v.58, p.1880-1888, 1975.

SANTOS, G.D. Perspectivas brasileira e mundial da produção de leveduras. In: CONGRESSO SOBRE USO DE LEVEDURA NA ALIMENTAÇÃO ANIMAL, 1., 2009. Anais... Campinas: [s.n.] 2009. p.1. (Resumo). 
SATTER, L.D.; SLYTER, L.L. Effect of ammonia concentration on rumen microbial protein production in vitro. Br. J. Nutr., v.32, p.199-208, 1974.

SISTEMA de análises estatísticas-SAEG. Versão 7.0. Viçosa: UFV, 1997. 150p.

SOUZA, W. Técnicas básicas de microscopia eletrônica aplicada às ciências biológicas. Departamento de Editoração Eletrônica da UENF, Campos dos Goytacazes. 1998.179p.

VAN SOEST, P.J. Nutrional ecology of the ruminant, 2.Ed. Cornell University Press, Ithaca. 1994.476p.
WANG, H.R.; WANG, M.Z.; L.H., Y. Effects of dietary sources on the microorganisms and fermentation of goats. J. Anim. Vet. Adv., v.8, p.13921401, 2009.

ZAMBOM, M.A.; ALCALDE, C.R.; HASHIMOTO,

J.H. et al. Parâmetros digestivos, produção e qualidade do leite de cabras Saanen recebendo rações com casca do grão de soja em substituição ao milho. Acta. Sci. Anim. Sci., v.29, p.309-316, 2007. 